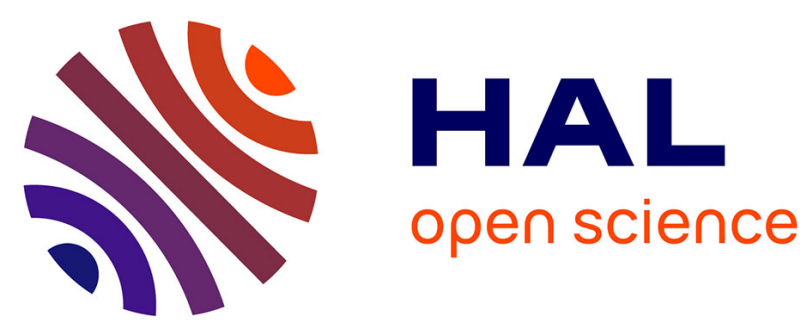

\title{
Orientation of the Intercostal Muscle Fibers in the Human Rib Cage
}

Damien Subit, Agnès Glacet, Mohsin Hamzah, Jeff Crandall

\section{To cite this version:}

Damien Subit, Agnès Glacet, Mohsin Hamzah, Jeff Crandall. Orientation of the Intercostal Muscle Fibers in the Human Rib Cage. Computer Methods in Biomechanics \& Biomedical Engineering, 2015, 18, pp.2064-2065. 10.1080/10255842.2015.1069624 . hal-02617535

\section{HAL Id: hal-02617535 \\ https://hal.science/hal-02617535}

Submitted on 25 May 2020

HAL is a multi-disciplinary open access archive for the deposit and dissemination of scientific research documents, whether they are published or not. The documents may come from teaching and research institutions in France or abroad, or from public or private research centers.
L'archive ouverte pluridisciplinaire HAL, est destinée au dépôt et à la diffusion de documents scientifiques de niveau recherche, publiés ou non, émanant des établissements d'enseignement et de recherche français ou étrangers, des laboratoires publics ou privés. 


\title{
Orientation of the intercostal muscle fibers in the human rib cage
}

\author{
D. Subit ${ }^{a, b}$ (D), A. Glacet ${ }^{a}$, M. Hamzah ${ }^{a}$ and J. Crandalla \\ aCenter for Applied Biomechanics, University of Virginia, Charlottesville, VA, USA; ${ }^{\text {b} A r t s ~ e t ~ M e t i e r s ~ P a r i s T e c h, ~ L B M / I n s t i t u t ~ d e ~ B i o m e c a n i q u e ~}$ \\ Humaine Georges Charpak, Paris, France
}

KEYWORDS PMHS; denuded rib cage; interpolation; dissection; angle

\section{Introduction}

Great improvement was achieved to protect vehicle occupants in case of a motor vehicle crashes thanks to the development of restraint systems such as seat belts and airbags. These systems increase the mechanical coupling between the human body and the vehicle to minimize the risk of severe injuries to the thorax and the head during a crash. As a result, they may induce injuries, such as rib fractures because of the loading applied to the thorax by the seat belt. Predicting and preventing injuries to the thorax is of particular interest as severe injuries occurred predominantly in the thorax in side impact (Welsh et al. 2009) and in elderly subjects. Significant efforts were put in the development of computational finite element models of the thorax to accurately predict the rib fractures created because of an impact ( $\mathrm{Li}$ et al. 2010). While the mechanical response of the individual human ribs has been widely studied (Charpail et al. 2005; Kindig 2009), only few studies reported on the contribution of the intercostal muscles (ICM) on the rib cage impact response (Vezin \& Berthet 2009). Furthermore, computational studies designed to assess the contribution of the ICM in the thorax impact response had to face the lack of detailed description of the ICM structure such as their thickness, and their fiber orientation (Poulard \& Subit 2015). Therefore, the goal of this study was to measure the orientation of the fibers in the ICM layers in the human thorax .

\section{Methods}

\subsection{Rib cage preparation}

The rib cage was extracted from one male post-mortem human subject (PMHS 571: 58 years, $175 \mathrm{~cm}, 82.8 \mathrm{~kg}$, cause of death: cardiac arrest). The PMHS was obtained, treated, and tested in accordance with the ethical guidelines in place at the University of Virginia - Center for Applied Biomechanics (USA). Cuts were made in the intervertebral discs between the second and third cervical vertebrae, and between the fourth and fifth lumbar vertebrae. The rib cage was denuded and eviscerated: the skin, fat, and superficial muscles other than the ICM (pectoral muscles, external oblique $\mathrm{m}$, serratus anterior $\mathrm{m}$, subscapularius $\mathrm{m}$, infrascapularis $\mathrm{m}$, erector major $\mathrm{m}$, rhomboid $\mathrm{m}$, and trapezius $\mathrm{m}$ ) were removed to expose the external ICM.

\subsection{ICM fibers orientation}

Equidistant points (every $20 \mathrm{~mm}$ ) were drawn on the left rib (1). From rib 1 , lines that follow the muscle fibers (the fiber line) were drawn all the way down to rib 12 or up to the rib level where the fiber line reached the posterior extremity of the rib. The intersection of the fiber lines with the ribs provided new reference points (Figure 1). The curvilinear position of these points along the ribs was documented with a measuring tape. For each intercostal space, the angle of the fiber line relative to the superior rib was calculated. The fiber angle was interpolated between each measured points to obtain an estimate of the continuous variation of the ICM angle along the ribs. A $0^{\circ}$-angle meant that the ICM fibers were orientated along the rib pointing toward to anterior direction, and the angle increased as the ICM fibers pointed down and toward posterior direction. This procedure was repeated for the internal layer, after the ICM external layer was carefully removed.

\section{Results and discussion}

The fibers' orientations were determined for each intercostal space (named after the number of the superior rib), and plotted as a function of the normalized curvilinear abscissa calculated for the superior rib (Figure 2). The orientation of the fibers in the external layer could be determined in the posterior rib cage, while the fiber angle in the

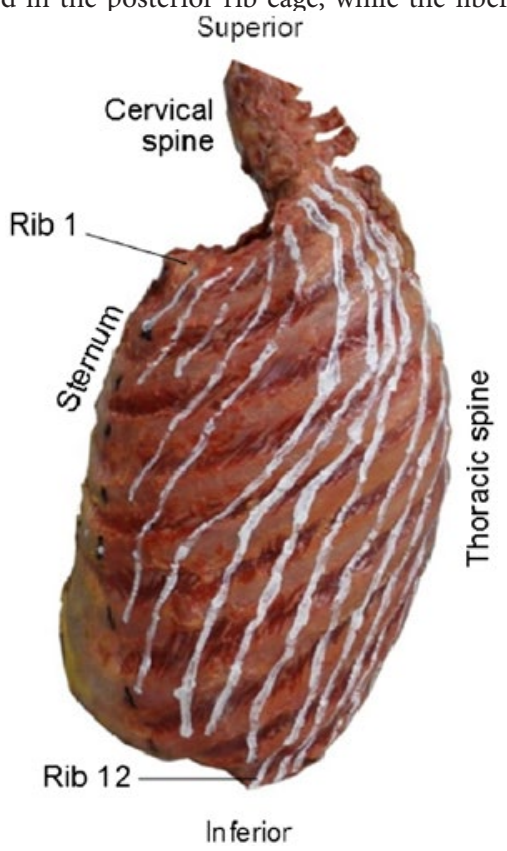

Figure 1. Extracted rib cage with the lines that show the direction of the ICM fibers. 


\section{External layer}

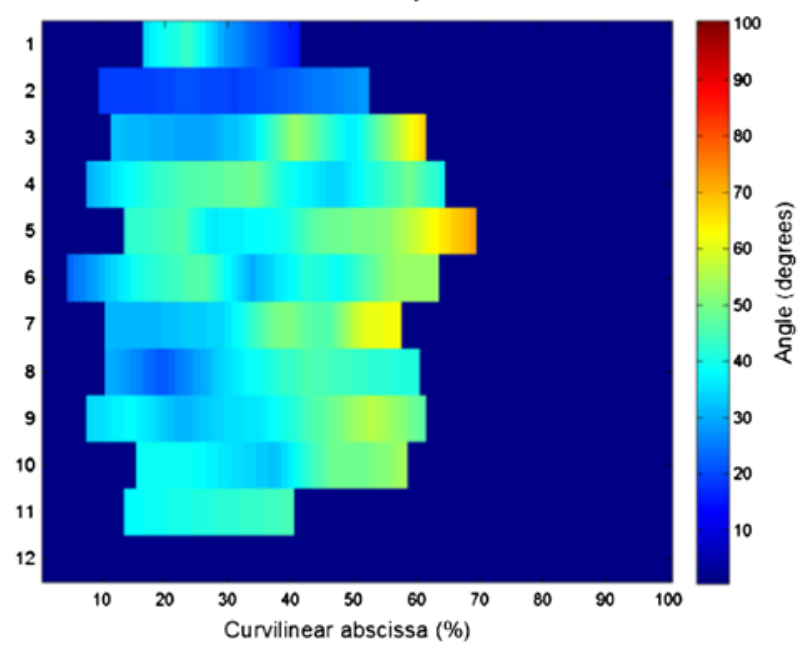

External layer
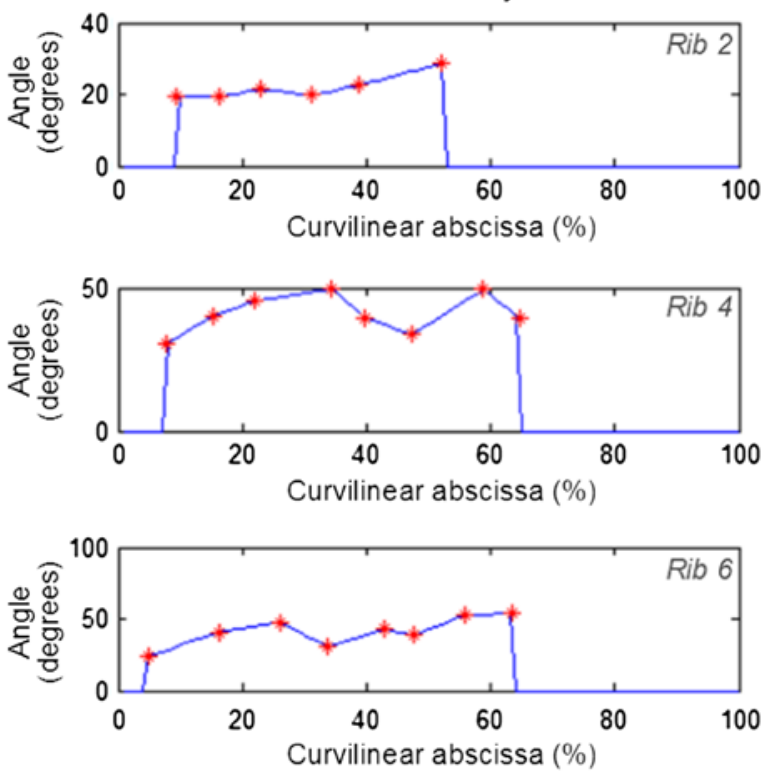

Internal layer

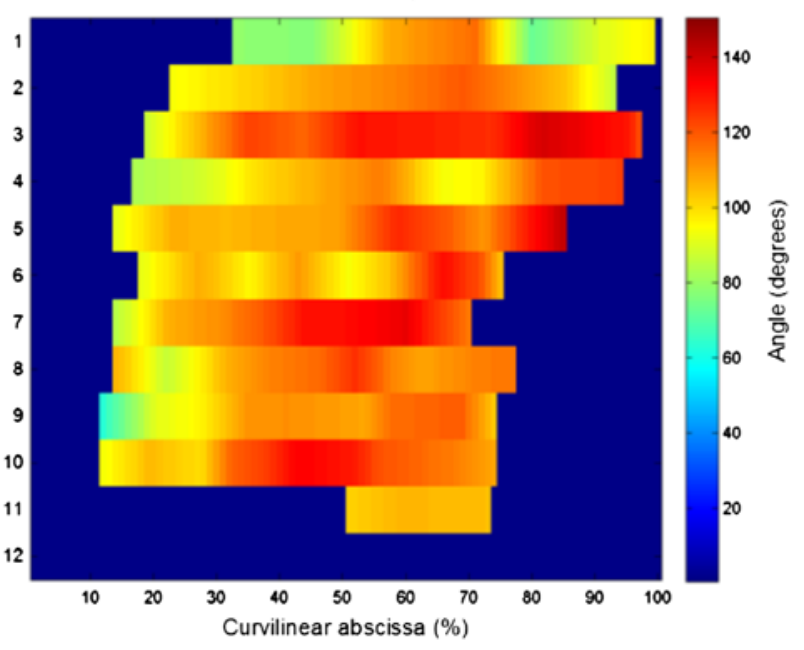

Internal layer
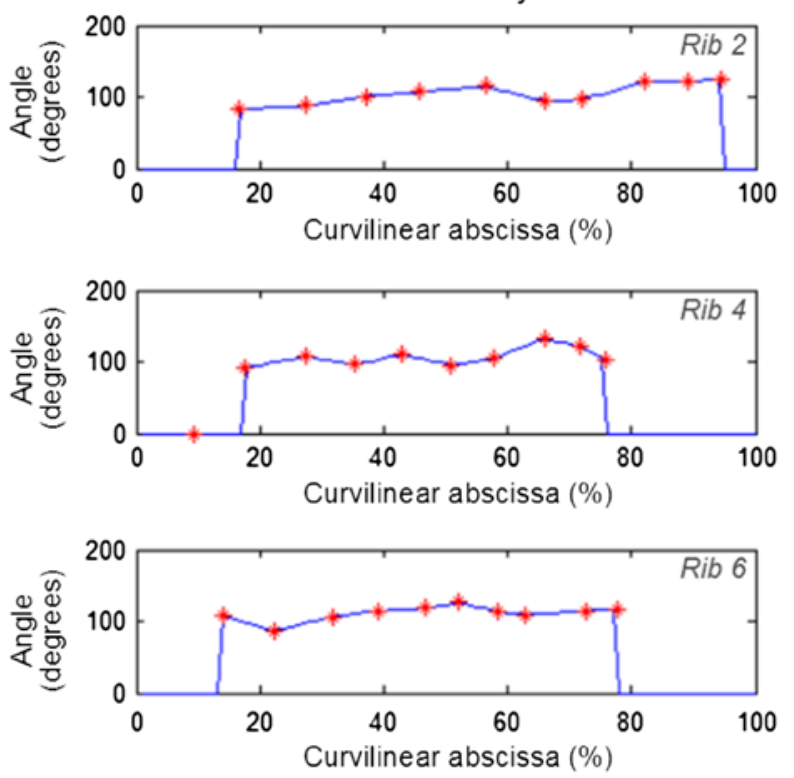

Figure 2. Orientation of the muscle fibers in the ICM external and internal layers.

internal layer could be estimated in a larger area that spreads in the anterior rib cage. Although the fiber angle and the type of tissue were difficult to identify near the ends of the rib, it was clear that the most anterior rib cage was covered by the internal layer only, while the posterior rib cage was covered by the external layer only. The ICM fibers in the external layer pointed forward (angle comprised between $3^{\circ}$ and $69^{\circ}$ ), while for the internal layer, the fibers pointed backward $\left(72^{\circ}-143^{\circ}\right)$. In the external layer, the fiber angles were lower in the superior and posterior aspects of the rib cage, while they were greater in the anterior aspect of the rib cage in the internal layer).

\section{Conclusions}

The fibers in the internal and external ICM layers have markedly different orientation, and cover different areas of the rib cage. These results need to be confirmed with a greater number of subjects, and the effects of the ICMs structural organization on the rib cage injury thresholds and mechanisms need to be quantified.

\section{ORCID}

D. Subit (D) http://orcid.org/0000-0003-1810-3086

\section{References}

Charpail E, Trosseille X, Petit P, Laporte S, Lavaste F, Vallancien G. 2005. Characterization of PHMS ribs: a new test methodology. Stapp Car Crash J. 49:1-16.

Kindig M. 2009. Tolerance to failure and geometric influences on the stiffness of human ribs under anterior-posterior loading [Master's thesis]. Charlottesville (VA): University of Virginia.

Li Z, Kindig MW, Subit D, Kent RW. 2010. Influence of mesh density, cortical thickness and material properties on human rib fracture prediction. Med Eng Phys. 32:998-1008.

Poulard D, Subit D. 2015. Unveiling the structural response of the rib cage: contribution of the intercostal muscles to thoracic response. Proceedings of the 24th International Technical Conference on the Enhanced Safety of the Vehicles. Paper 15-0387; Gothenburg, Sweden.

Vezin P, Berthet F. 2009. Structural characterization of human rib cage behaviour under dynamic loading. Stapp Car Crash J. 53:93-125.

Welsh R, Morris A, Thomas P, Lenard J, Barnes J, Otte D. 2009. Car to cat struck side impacts - a comparison between European accident data and directive 96/27/EC. IRCOBI Conference on the Biomechanics of Injury p.115-128; York, UK. 